\title{
Road kill of animals by highway traffic in the tropical forests of Mudumalai Tiger Reserve, southern India
}

\author{
N. Baskaran ${ }^{1} \&$ D. Boominathan ${ }^{2}$ \\ ${ }^{1}$ Bombay Natural History Society, Elephant Project, Bear Bungalow, Kargudi, The Nilgiris, Tamil Nadu 643211, India \\ Present Address: Asian Elephant Research and Conservation Centre, a Division of Asian Nature Conservation Foundation, Innova- \\ tion Centre First Floor, Indian Institute of Science, Bengaluru, Karnataka 560012, India \\ ${ }^{2}$ Department of Zoology, AVC College, Mannampandal, Mayiladuthrai, Tamil Nadu 609305, India \\ Present Address: World Wide Fund for Nature - India, Nilgiris and Eastern Ghats Landscape Programme, Lamp Society Building, \\ Masinagudi, The Nilgiris, Tamil Nadu 643223, India \\ Email: ${ }^{1}$ nagarajan.baskaran@gmail.com, ${ }^{2}$ nathan_d1 @ rediffmail.com
}

Date of publication (online): 26 February 2010 Date of publication (print): 26 February 2010 ISSN 0974-7907 (online) | 0974-7893 (print)

Editor: R.J. Ranjit Daniels

Editor's Note: The paper has been included despite the data being 10 years old, only to highlight the magnitude of the problem - a problem that might be many times higher at present and not really addressed.

\section{Manuscript details:}

Ms \# 02101

Received 26 November 2008

Final received 11 February 2010

Finally accepted 13 February 2010

Citation: Baskaran, N. \& D. Boominathan (2010) Road kill of animals by highway traffic in the tropical forests of Mudumalai Tiger Reserve, southern India. Journal of Threatened Taxa 2(3): 753-759.

Copyright: (c) N. Baskaran \& D. Boominathan 2010. Creative Commons Attribution 3.0 Unported License. JoTT allows unrestricted use of this article in any medium for non-profit purposes, reproduction and distribution by providing adequate credit to the authors and the source of publication

For Author Details, Author Contribution, Acknowledgements see end of this article

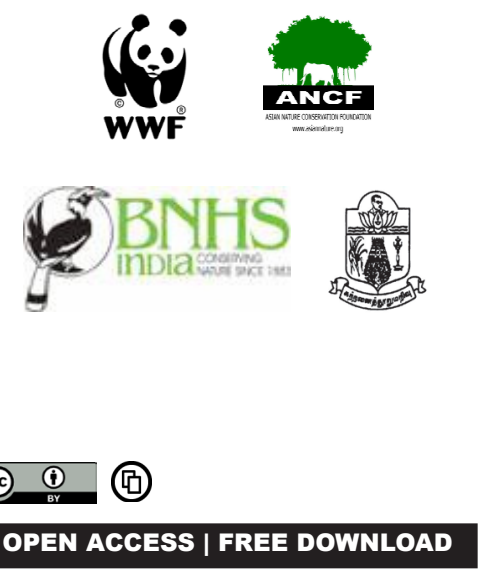

Abstract: Highways passing through natural reserves have adverse impact on wild animals. We evaluated the road kill of vertebrate fauna by vehicular traffic on highways at Mudumalai Tiger Reserve, southern India. In a fortnight's survey over $248 \mathrm{~km}$ across three public roads and opportunistic sampling method, a minimum of 180 road kills belonging to 40 species of amphibians, reptiles, birds and mammals were recorded between December 1998 and March 1999. Amphibians were the most affected taxa (53\%) of road kills followed by reptiles (22\%), mammals (18\%); including a leopard (Panthera pardus) and birds (7\%). Amphibians and reptiles are slow to react to vehicles and this along with the drivers' ignorance probably leads to higher mortality among these species. Road kills are significantly higher on highway stretches along rivers than those without water bodies nearby. We suggest the construction of flyovers, speed limits, speed breakers and signposts along the highways to reduce vehicle-caused wildlife mortalities.

Keywords: Highway impact, road kill, vertebrate, southern India

\section{INTRODUCTION}

Highways across wildlife refuges are an intrusion and affect the wildlife and its habitats adversely. The effects range from habitat loss and fragmentation (Burnett 1992; Richardson et al. 1997; Carr \& Fahrig 2001) to affecting the wild animal distribution pattern (Newmark et al. 1996), movement (Desai \& Baskaran 1998), breeding density (Reijnen et al. 1995), heterozygosity, genetic polymorphism (Reh \& Seitz 1990) and directly by mortality through collisions with vehicles (Oldham \& Swan 1991; Foster \& Humphrey 1995; Das et al. 2007; Row et al. 2007; Shwiff et al. 2007; Seshadri et al. 2009). The taxa affected ranges from mammals (Newmark 1992; Drews 1995; Newmark et al. 1996; Richardson et al. 1997) to birds (Reijnen et al. 1995; Drews 1995), reptiles (Rosen \& Lowe 1994; Drews 1995; Gokula 1997; Das et al. 2007) and amphibians (Reh \& Seitz 1990; Fahrig et al. 1995; Seshadri et al. 2009). More attention has been paid in North America, Australia, Europe and Africa to assess such impacts but Asia has not given the required attention to this aspect. In India, highways bisect many protected areas. It has been realized in recent years that highways cause severe impact to wildlife and their habitats (Gokula 1997; Gruisen 1998a Vijayakumar et al. 2001; Das et al. 2007). Therefore, the forest departments and non-governmental organizations in India are protesting against the construction of new highways and also the upgrading or widening of the existing roads in especially protected areas.

Mudumalai Tiger Reserve with adjoining reserved forests of Nilgiri North and Sathyamangalam forest divisions forms an important part of the Nilgiri Biosphere Reserve (located at the tri-junction of three southern states of Karnataka, Kerala and Tamil Nadu) (Desai \& Baskaran 1996). The Mudumalai Tiger Reserve has several roads including an inter-state highway cutting 


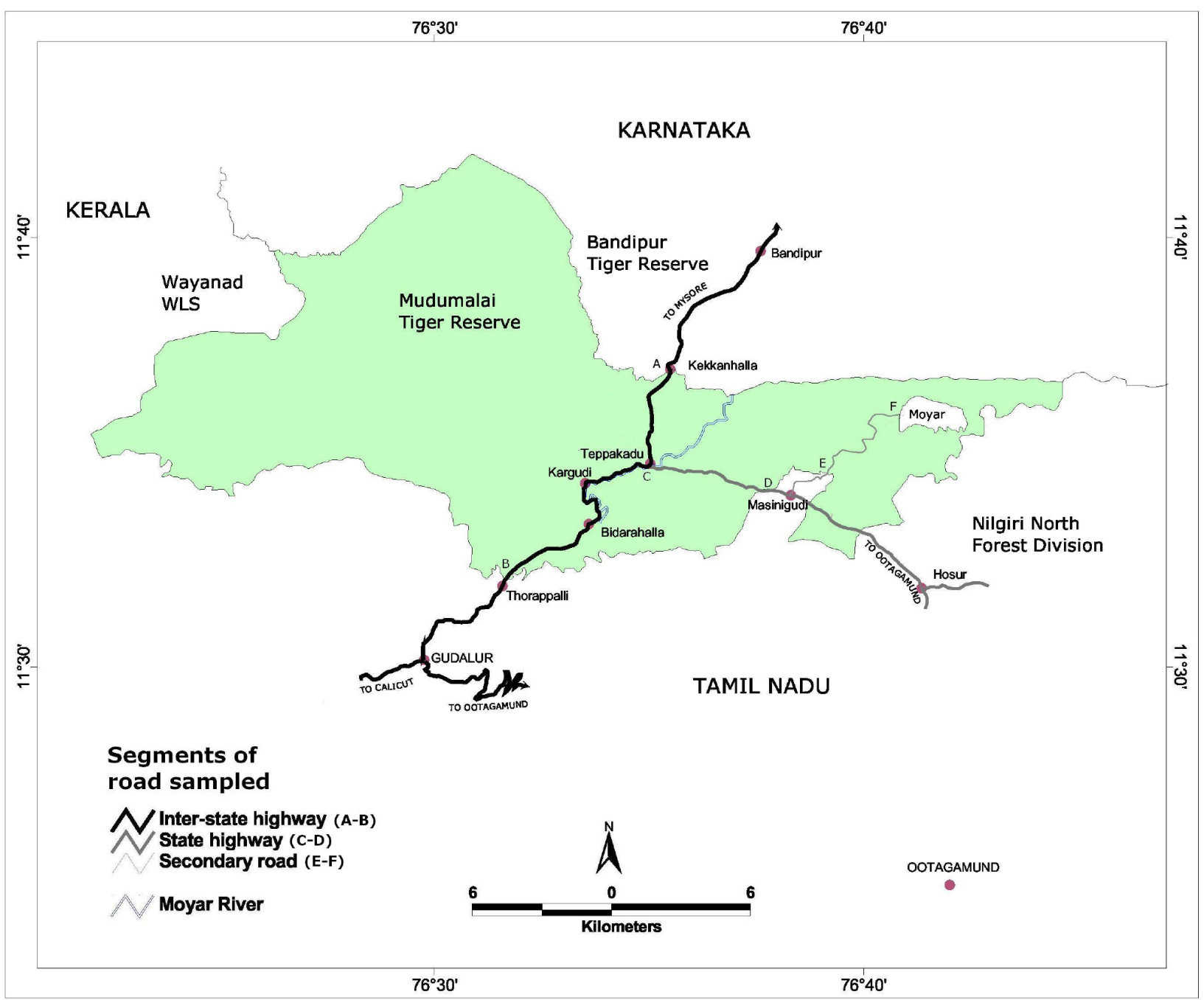

Image 1. Map of Mudumalai Tiger Reserve showing its adjoining forest divisions and the road segments used for the study.

through the reserve. These roads have been identified as the source of disturbance to wildlife both directly (road kills including that of endangered species) (Gokula 1997) and indirectly (noise and disturbance) (Daniel et al. 1995). Most of these observations are very subjective in nature, though undoubtedly, these roads have an adverse impact on wild animals (Daniel et al. 1995; Gokula 1997; Desai \& Baskaran 1998). However, the actual impact has not been quantified. Furthermore, there is also a proposal to develop a highway to connect Mysore (Karnataka) and Kozhikode (Kerala) Cities to Coimbatore City (Tamil Nadu) via Masinagudi, Anaikatty, Sigur and Bhavanisagar. At present, there is a road up to Sigur, but traffic level is comparatively less as this road ends at the village.

The proposal to divert the state highway from the Sariska Tiger Reserve in Rajasthan is a classic example of the highway impact on wild animals in India. In less than a year, one tiger Panthera tigris and two leopards Panthera pardus were killed by speeding vehicles on the state highway at Sariska Tiger Reserve (Gruisen 1998a).
The present study was carried out between December 1998 and March 1999, to evaluate the impact of vehicular traffic on vertebrate fauna in terms of animals killed by automobiles.

Although the study was carried out over a decade ago, the results are still important for the following reasons: there exists no detailed published data yet on the effects of vehicular traffic on the vertebrate fauna for the protected areas in the Nilgiri Biosphere Reserve, (which is part of the Nilgiri-Eastern Ghats and one among the developed landscape in Asia) (Leimgruber et al. 2003) with high biomass of large mammals. Further, with the recent economic growth of the nation, the traffic intensity would have increased substantially compared to the study period (1998-99) thus the published results would enhance the comparison of the present effect of highway traffic on the wildlife with the past findings to understand the current trend. 


\section{Study Area}

The Mudumalai Tiger Reserve is part of the Nilgiri Biosphere Reserve of the Western Ghats. It lies between $11^{\circ} 32^{\prime}-11^{\circ} 42^{\prime} N$ \& $76^{\circ} 20^{\prime}-76^{\circ} 40^{\prime} \mathrm{E}$ and is situated at the junction of three southern states, viz. Tamil Nadu, Kerala and Karnataka. The Reserve is surrounded by Bandipur Tiger Reserve in the north, Wayanad Wildlife Sanctuary in the west and Nilgiri North Forest Division in the east and south (Image 1) and covers an area of $321 \mathrm{~km}^{2}$, with an average elevation of $900-1000 \mathrm{~m}$. Moyar, the perennial river of the sanctuary flows eastwards. The sanctuary has three marked seasons, viz. dry season (January-April), southwest monsoon (May-August) and northeast monsoon (September-December). The annual rainfall varies from $600 \mathrm{~mm}$ in the east to $2000 \mathrm{~mm}$ in the west. Corresponding to the rainfall gradient, the vegetation changes from thorny scrub in the east, dry deciduous in the middle to moist and semi-evergreen forests in the west. The sanctuary with diverse vegetation types supports a large faunal assemblage including high abundance of threatened species like the Asian Elephant Elephas maximus and Indian Tiger.

\section{METHODS}

\section{Selection of study roads}

Three public roads located within the reserve were selected for quantifying the road kills and these include (1) an inter-state highway segment A-B), (2) a state highway (segment C-D), and (3) a secondary road (segment E-F) (Image 1). The inter-state highway connects the cultural capital of Karnataka, Mysore City, with the well-known hill station of southern India, Udhagamandalam, popularly known as Ooty (Image 1). The inter-state highway cuts through the forest areas of Karnataka (Bandipur Tiger Reserve) and Tamil Nadu, where it enters the Mudumalai forest in the north at the border post of Kekkanhalla and goes beyond the forest limits at Thorappalli. The stretch from Kekkanhalla to Thorappalli that runs through the reserve for a total length of $16 \mathrm{~km}$ with a relatively higher traffic intensity was identified as the inter-state highway sampling segment. The inter-state highway branches into a state highway at Teppakadu, leading to Udhagamandalam and beyond via Masinagudi, a small town. The stretch of $7 \mathrm{~km}$ between Teppakadu and Masinagudi was identified for the state highway sampling segment. The third sector of $8 \mathrm{~km}$ road that connects Masinagudi and Moyar was used as the secondary road sampling segment. Traffic intensity is less on this road compared to the inter-state and state highways. These three roads are different in their surrounding habitats and microhabitats but represent different networks of highways traverse through the reserve.

\section{Quantification of road kills}

To quantify the direct impact of roads on wild animals, the number of road kills that occurred on three roads were
Table 1. Summary of road kills of vertebrate fauna recorded at Mudumalai Tiger Reserve, southern India (a total $248 \mathrm{~km}$ covered in transect survey at the rate of $62 \mathrm{~km} / \mathrm{month}$ )

\begin{tabular}{|l|c|c|c|}
\hline \multirow{2}{*}{ Species name } & \multicolumn{3}{|c|}{ Number of road kills recorded } \\
\cline { 2 - 4 } & $\begin{array}{c}\text { Fortnight } \\
\text { transect } \\
\text { survey }\end{array}$ & $\begin{array}{c}\text { Opportunistic/ } \\
\text { incidental } \\
\text { sampling }\end{array}$ & $\begin{array}{c}\text { Total } \\
(\%)\end{array}$ \\
\hline Amphibians (3 species) & 59 & 37 & $96(53)$ \\
\hline Reptiles (16 species) & 26 & 14 & $40(22)$ \\
\hline Birds (8 species) & 05 & 07 & $12(07)$ \\
\hline Mammals (13 species) & 09 & 23 & $32(18)$ \\
\hline Total (40 species) & $\mathbf{9 9}$ & $\mathbf{8 1}$ & 180 \\
\hline
\end{tabular}

counted. The study was restricted to amphibians, reptiles, birds and mammals. To quantify the road kills, the three roads were surveyed systematically between 0600 and $0900 \mathrm{hr}$ twice a month at fortnightly intervals for four months from December 1998 to March 1999. In addition, using opportunistic sampling method, data on road kills (mostly mammals) were also collected during incidental visits and based on the information received from other researchers, department staff and local people. At every sighting of a road kill, information such as place, species name, number and status of the kill was recorded. The status of the kill was classified into two categories, such as fresh (killed within the last 24 hours) and old (killed more than 24 hours earlier) based on the condition of the carcass such as tissue and skin texture (soft/hard), and blood conditions. After recording the above details, the carcass was removed from the road and if unidentified, it was preserved in formalin for later identification. A total of 128, 56 and $64 \mathrm{~km}$ distances were walked respectively, on the inter-state highway, state highway and secondary road during the study period. Data on road kills collected on fortnightly and opportunistic sampling methods from the three roads during the study period were collated separately to arrive at the total number of road kills recorded in each sampling method.

\section{RESULTS}

\section{Road kills}

In total, 180 road kills belonging to 40 species were recorded both during periodic transect survey and opportunistic sampling methods (Table 1 ). Of the 180 road kills, 99 were recorded through fortnightly surveys of the three roads $(248 \mathrm{~km})$ over four months. The remaining 81 road kills were recorded through opportunistic sampling. Among the 180 road kills, amphibians were the most affected accounting for $53 \%$, followed by reptiles (22\%) and mammals $(18 \%)$. Birds were least affected by vehicular traffic and comprised $7 \%$ of the total kills. In terms of the number of species, reptiles (16 species) stood topmost followed by mammals (13 species) (Table 1). These figures are prob- 
Table 2. List of road kills recorded at Mudumalai Tiger Reserve, southern India (a total $248 \mathrm{~km}$ covered in transect survey at the rate of 62 km/month) between December 1998 and March 1999.

\begin{tabular}{|c|c|c|c|}
\hline \multirow[b]{2}{*}{ Species name } & \multirow[b]{2}{*}{ Common name } & \multicolumn{2}{|c|}{ Number of road kills recorded } \\
\hline & & $\begin{array}{c}\text { Fortnight } \\
\text { transect } \\
\text { survey }\end{array}$ & $\begin{array}{l}\text { Opportunistic/ } \\
\text { incidental } \\
\text { sampling }\end{array}$ \\
\hline \multicolumn{4}{|l|}{ Amphibians } \\
\hline Common Indian Toad & Duttaphrynus melanostictus & 59 & 35 \\
\hline Malabar Gliding Frog & Rhacophorus malabaricus & 0 & 1 \\
\hline Unidentified Frog & & 0 & 1 \\
\hline \multicolumn{4}{|l|}{ Reptiles } \\
\hline Russell's Viper & Daboia russelii & 2 & 1 \\
\hline Common Wolf Snake & Lycodon aulicus & 4 & 3 \\
\hline Bronze Back Snake & Dendrelaphis tristis & 2 & 1 \\
\hline Checkered Keelback Snake & Xenochrophis piscator & 0 & 1 \\
\hline Variegated Kukri Snake & Oligodon taeniolatus & 1 & 1 \\
\hline Green Keel Back Snake & Macropisthodon plumbicolor & 1 & 0 \\
\hline Common Cat Snake & Boiga trigonata & 1 & 1 \\
\hline Common Worm Snake & Ramphotyphlops braminus & 0 & 1 \\
\hline John's Earth Boa & Eryx johnii & 1 & 1 \\
\hline Beaked Worm Snake & Grypotyphlops acutus & 1 & 0 \\
\hline Golden Tree Snake & Chrysopelea ornata & 1 & 1 \\
\hline Buff-striped Keel Back & Amphiesma stolatum & 1 & 0 \\
\hline Common Green Whip Snake & Ahaetulla nasuta & 1 & 0 \\
\hline Common Garden Lizard & Calotes versicolor & 5 & 2 \\
\hline Common Skink & Eutropis carinata & 3 & 1 \\
\hline Chameleon & Chamaeleo zeylanicus & 2 & 0 \\
\hline \multicolumn{4}{|l|}{ Birds } \\
\hline Coucal & Centropus sinensis & 0 & 1 \\
\hline Common Indian Nightjar & Caprimulgus asiaticus & 2 & 0 \\
\hline Indian Myna & Acridotheres tristis & 0 & 2 \\
\hline Spotted Dove & Streptopelia chinensis & 0 & 2 \\
\hline Magpie Robin & Capsychus saularis & 0 & 1 \\
\hline Yellow-throated Sparrow & Petronia xanthocollis & 1 & 1 \\
\hline Hoopoe & Upupa epops & 1 & 0 \\
\hline Unidentified Birds & & 1 & 0 \\
\hline \multicolumn{4}{|l|}{ Mammals } \\
\hline Leopard & Panthera pardus & 0 & 1 \\
\hline Wild Boar & Sus scrofa & 0 & 1 \\
\hline Sambar & Rusa unicolor & 0 & 2 \\
\hline Chital & Axis axis & 0 & 1 \\
\hline Mouse Deer & Tragulus meminna & 0 & 1 \\
\hline Crest Grey Langur & Semnopithecus priam & 2 & 1 \\
\hline Bonnet Macaque & Macaca radiata & 0 & 6 \\
\hline Black-naped Hare & Lepus nigricollis & 0 & 3 \\
\hline Palm Civet & Paradoxurus hermaphroditus & 0 & 1 \\
\hline Palm Squirrel & Fanambulus palmarum & 0 & 1 \\
\hline Bandicoot & Bandicota sp. & 0 & 1 \\
\hline Mouse & Mus sp. & 7 & 3 \\
\hline Unidentified bat & & 0 & 1 \\
\hline Total & & 99 & 81 \\
\hline
\end{tabular}


ably an underestimate given that an unknown proportion of animals hit by vehicles are either eaten by carrion feeders or died in the nearby vegetation without being recorded. Among the road kills recorded, the Common Indian Toad Dattaphrynus melanostictus was the most susceptible species for the vehicular traffic (Table 2), which accounted for over $50 \%$ of the total road kills. It is important to note that vehicles killed endangered carnivores such as an adult Leopard and a Palm Civet Paradoxurus hermaphroditus during the four-month study period. Reptiles such as the Common Wolf Snake Lycodon aulicus, Common Garden Lizard Calotes versicolor, birds such as Indian Myna Acridotheres tristis, Spotted Dove Streptopelia chinensis, Yellow-throated Sparrow Petronia xanthocollis and Common Indian Nightjar Caprimulgus asiaticus, and mammals such as mouse Mus sp. were the most affected species. Among larger mammals, primates such as the Crested Grey Langur Semnopithecus priam and Bonnet Macaque Macaca radiata were highly affected, accounting for nine kills during the study period.

To understand the effect of highway stretches, especially those running parallel to a water source, on the wild animals, the number of road kills recorded in a sub-section of a given road (inter-state highway) running parallel to the river Moyar (between Teppakadu and Kargudi of $3.2 \mathrm{~km}$ ) was compared with a sub-section of the same road traversing away from water bodies (between Bidarhalla and Thorappalli of $5.1 \mathrm{~km}$ ) with similar adjoining major habitat conditions (Image 1). The sub-section of the road traversing parallel to water sources (between Teppakadu and Kargudi: $7.1 \mathrm{kills} / \mathrm{km}$ ) experienced a significantly more number of road kills $/ \mathrm{km}$ than the sub-section of the same road traversing away from water bodies (between Bidarhalla and Thorappalli: $1.8 \mathrm{kills} / \mathrm{km})\left(\chi^{2}=4.00, d f=1, P<\right.$ $0.05)$ with no variation in species composition. The results indicate that highways located parallel to water sources in a nature reserve are more detrimental to wild animals than those away from water areas.

\section{DISCUSSION}

The data on road kills revealed that vehicular traffic killed a minimum of 180 individuals of vertebrate fauna amphibian, reptile, bird and mammals of the reserve in four months. A study on road mortalities of snakes in Mudumalai carried out over six months (Gokula 1997) shows that out of seven species of snakes, the Common Vine Snake Ahaetulla nasutus was the most affected (12 out of 23 snake road kills) and estimated at 0.25 snakes/ $\mathrm{km}$ in 24 hours. In contrast, our study recorded 13 species of (27 individual) snakes with the Common Wolf Snake as the most affected species (seven road kills) in the four-month period. The difference could be attributed to the variation in sampling period, effort and the survey area. The most affected vertebrate fauna in the present study was amphibians (53\%) followed by reptiles (22\%), mammals (18\%) and birds ( $7 \%)$. The higher road mortality of amphibians and reptiles could be attributed to their slow mobility, not reacting quickly to vehicles and the fact that drivers are less likely to notice these animals because of ignorance. Among the reptile road kills, snakes (13 out of 16 species) accounted for the highest (67\%). A similar finding has been made by Das et al. (2007) at Kaziranga National Park, northeastern India who attributed the slow movement and use of roads as substrate for thermoregulation by snakes for the higher mortality. Rosen \& Lowe (1994) estimated ten to hundreds of millions of snakes having been killed by automobiles in the United States and reasoned that resting or coiling of snakes on the road surface especially during spring season for warmth is a contributing factor to the high road mortality of snakes. Lower susceptibility of birds to vehicular hits could be due to their ability to fly fast.

Among the amphibian road kills recorded in the present investigation, Duttaphrynus melanostictus was the most affected (98\%), as reported in another study in the Anamalai Hills (Vijayakumar et al. 2001). Our results, though arguably due to the higher 'relative abundance' of this species, here in this area, perfectly accord with Vijayakumar et al. (2001), wherein the family Bufonidae, represented solely by $D$. melanostictus constituted up to almost half $(46.6 \%, n=144)$ of total amphibian road kills in Anaimalai Hills, which is present ca. 150 airline km southwest of our study area. The foraging nature of these toads, which are very fond of gathering near street lamps and vehicle head lights to feast on insects (Daniels 2005) coupled with their highly eurytopic and human commensally traits (Daniel 2002; Daniels 2005) could also be the possible reasons for their higher susceptibility of becoming road kill victims. Among the mammalian fauna, the Bonnet Macaque and Crested Grey Langur come close to the road to beg from tourists leading to higher incidents of mortality due to highway traffic, as reported for Yellow Baboons in Mikumi National park, Tanzania (Drews 1995). Sometimes the sudden movement of langur across the road also contributes to high mortality of this species (N. Baskaran pers. comm.). Most of the mammalian road kills recorded in the present study are nocturnal (mouse, bandicoot, Blacknaped Hare, Sambar, Leopard, Palm Civet and bat) species that could have been killed while crossing the roads, as they get blinded by the vehicle's headlights. Besides an adult leopard, a leopard cub at Mudumalai Tiger Reserve in February 1998 and an adult tiger at Bandipur, were killed by speeding vehicles in 2006 (N. Baskaran pers. obs.). Though these figures seem to be very small compared to other species, such loss is unbearable considering their low population density. There are several places where large cats have been killed by highway traffic in India. In Sariska Tiger Reserve, Rajasthan, one tigress and two leopards were killed by highway traffic in a year (Gruisen 1998a) and several leopards in a two-month period in Corbett National 
Park, Uttar Pradesh (Gruisen 1998b). Similarly, in Florida, collision with motor vehicles is a major cause of mortality of the endangered Florida Panther Puma concolor coryi, accounting for $49 \%$ of the documented deaths (Maehr et al. 1991). In Africa, endangered species such as the African Elephant Loxodonta africana $(n=2)$, Wild dog Lycaon pictus $(n=3)$ and Panthera leo krugeri $(n=1)$ were killed by vehicles during a period of 19 months (Drews 1995). These reports indicate that such problems are increasing in recent years.

The present study is preliminary in nature as it was a short term study and has some caveats like actual rate of mortality per day and seasonal variability on the rate of road kill which could not be worked out. A more detailed year round study will enable us to understand better the impact of vehicular traffic. Nevertheless, this study indicates that roads have a high impact on wildlife.

\section{CONCLUSIONS AND RECOMMENDATIONS}

The present study shows that highways have adverse impact on wildlife including endangered species. During the four-month study, a leopard was killed by highway traffic apart from other endangered species. Earlier records indicate that Tiger, Leopard, Sloth Bear, Leopard Cat, Small Indian Civet and Gaur have been killed by vehicular traffic. We make the following recommendations apart from simple measures like speed limits, breakers and adequate signposts at the roadsides of the reserve:

- It is not advisable to permit any changes in the existing highways that would increase the traffic load or speed limit as such changes will increase road kill rate further. Additionally, the proposed new highway to Coimbatore via Masinagudi, Sigur, Bhavanisagar should not be developed as alternative highways already exist (from Kozhikode to Coimbatore via Palghat and Mysore to Coimbatore via Chamarajnagara and Hasanur) and the new highway would increase the traffic load, both in Mudumalai and Bandipur Tiger Reserves.

- Including the first author's experience in Mudumalai since 1990 on an elephant ecology long-term study (Daniel et al. 1995), we have come across a large number of road kills in addition to the fact that wild animals including elephants have to wait for long hours due to vehicular traffic to access the water source especially between Teppakadu and Kargudi. Here the highway runs parallel to Moyar River. We suggest the construction of fly-overs for vehicular traffic across the traditional footpaths of wild animals (Kalhalla, Nadu-camp and Kargudi watchtower) leading to Moyar River to reduce the road kill rate as well as to improve the access of the water source to wild animals.

\section{REFERENCES}

Burnett, S. (1992). Effects of a rainforest road on movements of small mammals: mechanisms and implications. Wildlife Research 19: 95-104.

Carr, L.W. \& L. Fahrig (2001). Effect of road traffic on two amphibian species of differing vagility. Conservation Biology 15 : 1071-1078.

Daniel, J.C. (2002). The Book of Indian Reptiles and Amphibians. Oxford University Press, Bombay Natural History Society Bombay, India, 238pp.

Daniel, J.C., A.A. Desai, N. Sivaganesan, H.S. Datye, S. Rameshkumar, N. Baskaran, M. Balasubramanian \& S. Swaminathan (1995). Ecology of the Asian elephant. Final Report 1987-1994. Bombay Natural History Society, Bombay.

Daniels, R.J.R. (2005). Amphibians of Peninsular India. University Press, Hyderabad, India, 268pp+46 plates

Das, A., M.F. Ahmed, B.P. Lahkar \& P. Sharma (2007). A preliminary report of reptilian mortality on road due to vehicular movement near Kaziranga National Park, Assam, India. Zoos' Print Journal 22(7): 2742-2744.

Desai, A.A. \& N. Baskaran (1996). Impact of human activities on the ranging behaviour of elephants in the Nilgiri Biosphere Reserve, South India. Journal of Bombay Natural History Society 93(3): 559-569.

Desai, A.A. \& N. Baskaran (1998). Ecology of Malabar Giant Squirrel (Ratufa indica) in Mudumalai Wildlife Sanctuary, South India. Technical Report Bombay Natural History Society, Bombay.

Drews, C. (1995). Road kill of animals by public traffic in Mikumi National Park, Tanzania with notes on baboon mortality. African Journal of Ecology 33: 89-100.

Fahrig, L., J.H. Pedlar, S.E. Pope, P.D. Taylor \& J.F. Wegner (1995). Effect of road traffic on amphibian density. Biological Conservation 73: 177-182.

Foster, M.L. \& S.R. Humphrey (1995). Use of highway underpasses by Florida Panthers and other Wildlife. Wildlife Society Bulletin 23(1): 95-100.

Gokula, V. (1997). Impact of vehicular traffic on snakes in Mudumalai Wildlife Sanctuary. Cobra 27: 26

Gruisen, J.V. (1998a). Rajasthan. Tiger Link 4(1): 10-11.

Gruisen, J.V. (1998b). Uttar Pradesh. Tiger Link 4(1): 14.

Leimgruber, P, J.B. Gagnon, C. Wemmer, D.S. Kelly, M.A. Songer \& E.R. Selig (2003). Fragmentation of Asia's remaining wild lands: implications for Asian elephant conservation. Animal Conservation 6: 347-358.

Maehr, D.S., E.D. Land \& M.E. Roelke (1991). Mortality patterns of panthers in southwest Florida, pp. 201-207. In: Proceeding of Annual Conference of Southeast Association of Fish and Wildlife Agencies 45.

Newmark, W.D. (1992). The selection and design of nature reserves for the conservation of living resources. In: Managing protected areas in Africa. (Compiler W.J. Lusigi). UNESCO, Paris.

Newmark, W.D., J.I. Boshe, H.I. Sariko \& G.K. Makumbule (1996). Effects of highway on large mammals in Mikumi National Park, Tanzania. African Journal of Ecology 34: 15-31.

Oldham, R.S. \& M.J.S. Swan (1991). Conservation of amphibian populations in Britain, pp. 141-157. In: Seitz, A. \& V. Lowschcke (eds.). Species conservation: a population biological approach. Birkhauser Verlag, Basel.

Reh, W. \& A. Seitz (1990). The influence of land use on the genetic structure of populations of the common frog Rana temporaria. Biological Conservation 54: 239-49.

Reijnen, R., R. Foppen, C.T. Braak \& J. Thissen (1995). The effects of car traffic on breeding bird populations in woodland III: Reduction of density in relation to the proximity of main 
roads. Journal of Applied ecology 32: 187-202.

Richardson, J.H., R.F. Shore \& J.R. Treweek (1997). Are major roads a barrier to small mammals? Journal of Zoology London 243: 840-846.

Rosen, C. \& C.H. Lowe (1994). Highway mortality of snakes in the Sonoran desert of Southern Arizona. Biological Conservation 68: 143-8.

Row, J.R., G. Blouin-Demers \& P.J. Wheatherhead (2007). Demographic effect of road mortality in black rat snakes (Elaphe obsolete). Biological Conservation 137 117-124.

Seshadri, K.S., A. Yadev \& K.V. Gururaja (2009). Road kills of amphibians in different land use areas from Sharavathi river basin, central Western Ghats India. Journal of Threatened Taxa 1(11): 549-552.

Shwiff, S.A., H.T. Smith, R.M. Engeman, R.M. Barry, R.J. Rossmanith \& M. Nelson (2007). Bioeconomic analysis of herpetofauna raod-kills in a Florida State Park. Ecological Economics 64: 181-85.

Vijayakumar, S.P., K. Vasudevan \& N.M. Ishwar (2001). Hepetofaunal mortality on the roads in the Anamalai Hills, southern Western Ghats. Hamadryad 26(2): 265-272.
Author Detail: Dr. N. BASKARAN is presently a Sr. Scientist at the ANCF, studying Asian Elephant and its habitats across Western and Eastern Ghats and Eastern Himalayas landscapes since 1990. MR. D. Boominathan is presently a Sr. Project Officer in Western Ghats Landscape Program of WWF, studying the human-elephant conflict since 2003.

Author Contribution: The first author designed the study, compiled the data and wrote this manuscript, while the second author conducted the field surveys of this study during his Master of Science degree.

Acknowledgements: We are thankful to the Forest Department of Tamil Nadu especially to Mr. P.S. Katwal IFS, former Chief Wildlife Warden and Mr. A. Udhayan IFS, former Wildlife Warden, Mudumalai Wildlife Sanctuary for permitting the study. We thank Mr. A.A. Desai, Co-chairman IUCN Asian Elephant Specialist Group for his valuable suggestion to the study. We also acknowledge the help rendered by Mr. S. Swaminathan, Bombay Natural History Society and Mr. R. Arumugam and Dr. C. Arivazhagan, Indian Institute of Science during the fieldwork and Mr. Avinash K.G., Asian Nature Conservation Foundation for GIS support. 